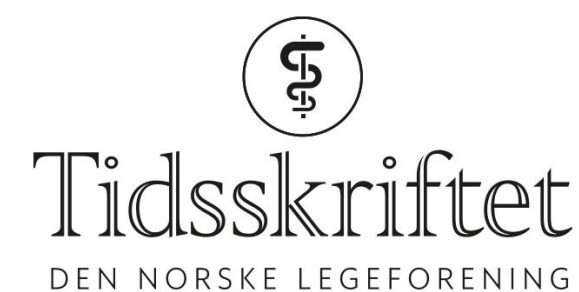

\title{
Screening for den enkelte og kunnskap for alle
}

DEBATT

\section{METTE KALAGER}

E-post: mkalager@hsph.harvard.edu Mette Kalager er medisinsk redaktør i Tidsskriftet. Hun er lege og ph.d., førsteamanuensis og leder av Klinisk effektforskningsgruppe ved Universitetet i Oslo og Oslo universitetssykehus. Forfatter har fylt ut ICMJE-skjemaet og oppgir ingen interessekonflikter.

\section{CAMILLA STOLTENBERG}

Camilla Stoltenberg er lege, dr.med. i epidemiologi, direktør for Folkehelseinstituttet og professor II ved Universitetet i Bergen.

Forfatter har fylt ut ICMJE-skjemaet og oppgir ingen interessekonflikter.

Norge får sitt tredje kreftscreeningprogram. Nå må vi tenke nytt for å utnytte vår fordel som kunnskapsgenerator for helsetjenestene og folkehelsearbeidet.

Helsedirektoratet forbereder i disse dager et nytt masseunders $ø$ kelsesprogram for tarmkreft. Planene skal være ferdige til høsten. Norge får derved sitt tredje kreftscreeningprogram.

Når man starter screening med én test for hele befolkningen, er det umulig å ta et skritt tilbake for å finne ut om en annen test hadde vært bedre. Derfor må vi innføre tarmkreftscreening som en kontinuerlig systematisk og randomisert utprøving av hva som er den beste testen. Bare slik kan vi få sårt tiltrengt kunnskap som står seg over tid.

Vi må være sikre på at en ny test eller behandling virker, at den er trygg å bruke og ikke fører til alvorlige bivirkninger eller skader, og at kostnadene står i et akseptabelt forhold til effektene - og vi bør vite at testen eller behandlingen totalt sett er bedre enn alternativene. Randomiserte utprøvinger gir den mest pålitelige kunnskapen når man sammenligner to eller flere tester. Hvordan kan vi få dette til i et program som er del av de ordinære tjenestene?

\section{Screening og forskning}

Nye legemidler godkjennes ikke uten randomiserte utprøvinger. Slik har det vært i flere tiår, og mange liv er spart ved at unyttige eller farlige behandlinger ikke innføres på norske sykehus og legekontorer. Problemstillingen er ytterligere aktualisert de siste årene fordi vi i dag ofte har flere mulige behandlinger for samme tilstand. Spørsmålet er da ikke lenger bare hva som virker, men hva som virker best.

Når det gjelder andre helsetiltak - enten det dreier seg om screeningprogrammer, ikkemedikamentell behandling eller samfunnsmessige folkehelsetiltak - bruker vi i altfor liten 
grad randomiserte utprøvinger. Det er mange grunner til dette, men en vesentlig hindring er at randomisering hittil har vært forbeholdt forskningsprosjekter. Fordi screening som regel er kategorisert som helsetjeneste og ikke som forskning, brukes vanligvis ikke randomisering for å finne ut hvilket tiltak som virker best. Dette hindrer at vi får kunnskap om hva som er det beste tiltaket. På tross av at alt ligger til rette for at vi i Norge kan få slik kunnskap enklere og billigere enn i de fleste andre land. Det nye screeningprogrammet for tarmkreft bør organiseres slik at det både vil gi de beste tjenestene for den enkelte og den beste vitenskapelige kunnskapen om hvilken screeningmetode som til enhver tid er den beste. For å få dette til må helsetjenester - i dette tilfellet screening - veves tettere sammen med forskning. Slik kan programmet også tenkes å bli en modell for fremtidige kontinuerlige systematiske utprøvinger av behandling så vel som screening og folkehelsetiltak.

\section{Hvilken screeningtest er best?}

Beslutningen om å innføre tarmkreftscreening i Norge er klok. Nasjonalt råd for prioritering i helsetjenesten anbefalte dette etter en grundig prosess. Men hvilken screeningtest er best for Norges befolkning? Det er det foreløpig ingen som vet.

Flere screeningtester for tarmkreft er aktuelle: blod i avføring, kikkertundersøkelse av den nederste delen av tarmen (sigmoidoskopi) og kikkertundersøkelse av hele tarmen (koloskopi). Testene har ulike fordeler og ulemper, krever ulik innsats fra pasientene og helsevesenet, og kostnadene er forskjellige. Det er uklart hvilken av de tre testene som er den beste, fordi det ennå ikke foreligger resultater fra sammenlignende studier. Dermed vet vi ikke hvilken test som har størst virkning på tarmkreft og overlevelse. Og derfor er det vanskelig å beslutte hvilken test man bør tilby befolkningen.

\section{Utprøving med randomisering}

Å tilby ulike personer ulike tester ved loddtrekning i et screeningprogram bryter ikke med kravet om likeverdige tjenester for alle, så lenge det ikke foreligger dokumentasjon for at den ene testen er bedre enn den andre.

Først når man har sammenlignet de tre testene i ca. ti år, vil man finne ut hvilken som er best. Om ti år må derfor masseundersøkelsesprogrammet gå videre med den beste testen og fase ut de andre. Innen den tid vil det sannsynligvis finnes nye tester som vi ikke kjenner til i dag, som den beste testen igjen må testes mot ved hjelp av ny randomisering.

Screeningprogrammet må derfor planlegges som en dynamisk prosess der ideen er at pasientene og befolkningen til enhver tid skal få tilbud om de beste testene. Ikke bare er prinsippet om likeverdig behandling ivaretatt med et slikt opplegg, men også ønsket om å gi befolkningen den mest effektive testen. Det vil innebære at alle deltagere i screeningprogrammer deltar i forskning og bidrar til ny kunnskap.

I Norge har vi en offentlig helsetjeneste med i prinsippet lik tilgang for alle, og en stabil befolkning som kan følges over tid ved hjelp av helseregistre og folkeregister. Det er det få andre land som har. Vi har de beste forutsetninger for å produsere kunnskap om hva som er de beste testene, den beste behandlingen og de beste folkehelsetiltakene.

Vi bør vi i mye større grad enn i dag ta i bruk systematisk og kontinuerlig utprøving med randomisering. Det vil komme pasientene og befolkningen til gode, i Norge og resten av verden.

Publisert: 22. mai 2017. Tidsskr Nor Legeforen. DOI: 10.4045/tidsskr.17.0445

Mottatt 15.5.2017, godkjent 19.5.2017. Setteredaktør: Pål Gulbrandsen.

(C) Tidsskrift for Den norske legeforening 2020. Lastet ned fra tidsskriftet.no 